\title{
Pathogenicity of Meloidogyne incognita on Cucurbita Pepo
}

\author{
Pc. Lalhruaitluanga* and Koilash Hazarika
}

Department of Nematology, Assam Agricultural University, Jorhat, Assam, India

*Corresponding author

\begin{tabular}{l}
\hline K e y w o r d s \\
$\begin{array}{l}\text { M. incognita, } \\
\text { Pathogenicity, } \\
\text { Pumpkin }\end{array}$ \\
\hline Article Info \\
$\begin{array}{l}\text { Accepted: } \\
\text { 07 October } 2020 \\
\text { Available Online: } \\
10 \text { November } 2020\end{array}$ \\
\hline
\end{tabular}

\section{Introduction}

Pumpkin (Cucurbita pepo) is a climber as well as trailer and able to complete their life cycle within one growing season. It is one of the widely grown vegetables. It is rich in flavonoids, poly-phenolics and antioxidants including lutein and both alpha and beta carotene, the latter of which generates vitamin
A in the body. The colour of pumpkin is derived from the orange pigments abundant in them. In India, it is grown mainly in Bihar, West Bengal, Tamil Nadu, Karnataka, Madhya Pradesh, Uttar Pradesh, Orissa and Assam. India has total production of 1079 thousand MT according to estimate on 201718 horticultural crops (Anonymous, 2018). 
Pumpkin belongs to the family Cucurbitaceae. Some other members of this family are cucumber, gherkin, sponge gourd, ridge gourd, ash gourd, pointed gourd, snake gourd, bitter gourd, long melon etc. The plants belong to this family are highly susceptible to the attack of pest and diseases. Among them root knot nematode were first discovered as a pest of cucumber by Berkeley in 1855 at England. It was reported that root knot nematode feed on more than 3000 hosts plants and globally it destroys 29-30 per cent of vegetable crops. However, in Assam, it caused 17.92 per cent of an avoidable yield loss in the cucumber (Anonymous, 2011). In general, $M$. incognita produces egg masses on galls and it contains more that 250-500 eggs. Such reproductions are governed by many factors like susceptible host, nematode inoculum density and environmental conditions. Our main aim is to lessen the pathogen density at below ETL (economic injury level). So, it is crucial to conduct a study on the pathogen density levels against a susceptible host under controlled condition and it helps in the making proper decisions for the integrated management of pathogen. Keeping this in view an experiment was carried out on pathogenicity of $M$. incognita on chickpea.

\section{Materials and Methods}

The experiment was carried out in the net house of Department of Nematology during rabi season 2019-20 to study the pathogenicity of $M$. incognita on pumpkin. Required numbers of earthen pots were collected, cleaned and dried under the sun. Pots were filled with $2 \mathrm{~kg}$ autoclaved soil, placing few sterilized broken bricks at the bottom. Then, these pots were labelled according to the allotted treatments and replications. The pumpkin cultivar Karbi-I was used to test the pathogenicity of $M$. incognita on pumpkin. The pots were arranged in completely randomized design (CRD) with 5 replications for each treatment. The seedling were inoculated with second stage juvenile of $M$. incognita at three leaf stage in a logarithmic series of check, associated check, 10, 100, 1000, 10,000 juveniles $\left(\mathrm{J}_{2}\right)$ per $\mathrm{kg}$ of soil. The plants were watered regularly. Observations on different plant parameters were taken after 60 days of inoculation. Plant heights were recorded before uprooting the plants. The potted plants were uprooted very carefully and the root system was washed carefully with tap water so that there was no loss of roots and egg masses. Number of galls and egg masses per root system were recorded. Similarly, fresh shoot and root weights were taken. For recording dry weight, the plants along with their root systems were packed in paper bags labelled according to the treatments. The bags were kept in an oven at $60^{\circ} \mathrm{C}$ till constant weight of dried plant materials was obtained. The nematode population in the pot soil was determined by washing 250cc of homogenously mixed pot soil by modified Cobb's sieving and decanting technique. Statistical analysis was performed by using WASP 1.0 software.

Reproductive rate $=\frac{\text { Final nematode population }}{\text { Initial nematode population }}$

\section{Results and Discussion}

In the present experiment mean data on plant growth parameters viz., plant height, fresh and dry weight of shoot and root, number of galls, number of egg masses, final nematode population in soil and reproductive rate in different treatments are presented in Table 1 and 2 along with their $C D$ values and illustrated in Fig. 1 to 7 . The results obtained in the study of pathogenicity of root-knot nematode $M$. incognita on pumpkin indicated that plants became stunted with the increase of inoculum level of the nematode. 
Table.1 Effect of different inoculum levels of Meloidogyne incognita on plant growth parameters of Pumpkin

\begin{tabular}{|c|c|c|c|c|c|}
\hline $\begin{array}{c}\text { Inoculum level } \\
\left(\mathbf{J}_{2} / \mathrm{kg} \text { soil }\right)\end{array}$ & $\begin{array}{c}\text { Plant height } \\
\text { (cm) }\end{array}$ & $\begin{array}{c}\text { Fresh weight } \\
\text { of shoot (g) }\end{array}$ & $\begin{array}{l}\text { Dry weight } \\
\text { of shoot (g) }\end{array}$ & $\begin{array}{c}\text { Fresh weight } \\
\text { of } \operatorname{root}(\mathrm{g})\end{array}$ & $\begin{array}{c}\text { Dry weight } \\
\text { of root (g) }\end{array}$ \\
\hline $\mathbf{T}_{1}:$ Check & $142.20^{\mathrm{a}}$ & $41.26^{\mathrm{a}}$ & $7.08^{\mathrm{a}}$ & $21.04^{\mathrm{a}}$ & $6.85^{\mathrm{a}}$ \\
\hline$T_{2}:$ Associated check & $141.80^{\mathrm{ab}}$ & $41.14^{\mathrm{a}}$ & $7.00^{\mathrm{a}}$ & $20.89^{\mathrm{a}}$ & $6.72^{\mathrm{a}}$ \\
\hline$T_{3}: 10$ & $140.30^{\mathrm{ab}}$ & $40.70^{\mathrm{a}}$ & $6.72^{\mathrm{a}}$ & $20.62^{\mathrm{a}}$ & $6.51^{\mathrm{a}}$ \\
\hline$T_{4}: 100$ & $139.82^{b}$ & $39.30^{\mathrm{a}}$ & $5.78^{\mathrm{a}}$ & $18.98^{\mathrm{a}}$ & $5.89^{\mathrm{a}}$ \\
\hline$T_{5}: 1000$ & $82.70^{c}$ & $26.07^{\mathrm{b}}$ & $3.14^{\mathrm{b}}$ & $13.64^{\mathrm{b}}$ & $2.72^{b}$ \\
\hline$T_{6}: \mathbf{1 0 , 0 0 0}$ & $43.20^{d}$ & $17.00^{\mathrm{c}}$ & $1.27^{\mathrm{c}}$ & $9.98^{c}$ & $1.01^{\mathrm{c}}$ \\
\hline S.Ed. $( \pm)$ & 1.079 & 1.038 & 0.709 & 1.174 & 0.825 \\
\hline $\mathrm{CD}_{0.05}$ & 2.229 & 2.144 & 1.464 & 2.423 & 1.705 \\
\hline
\end{tabular}

Mean followed by the same letter in the superscript(s) are statistically at par

Table.2 Effect of different inoculum levels of Meloidogyne incognita on number of galls, eggmasses and nematode population on Pumpkin

\begin{tabular}{|c|c|c|c|c|}
\hline $\begin{array}{c}\text { Inoculum level } \\
\left(\mathbf{J}_{2} / \mathrm{kg} \text { soil }\right)\end{array}$ & $\begin{array}{c}\text { No. of galls/root } \\
\text { system }\end{array}$ & $\begin{array}{c}\text { No. of eggmasses/root } \\
\text { system }\end{array}$ & $\begin{array}{l}\text { Final nematode population } \\
\text { ( } 200 \text { cc of soil) }\end{array}$ & $\begin{array}{l}\text { Reproductive rate } \\
(\%)\end{array}$ \\
\hline $\mathbf{T}_{1}:$ Check & $\begin{array}{c}0.00 \\
(0.707)^{\mathrm{e}}\end{array}$ & $\begin{array}{c}0.00 \\
(0.707)^{\mathrm{e}}\end{array}$ & $\begin{array}{c}0.00 \\
(0.707)^{\mathrm{e}}\end{array}$ & 0.00 \\
\hline $\mathbf{T}_{2}$ : Associated check & $\begin{array}{c}0.00 \\
(0.707)^{\mathrm{e}}\end{array}$ & $\begin{array}{c}0.00 \\
(0.707)^{\mathrm{e}}\end{array}$ & $\begin{array}{c}0.00 \\
(0.707)^{\mathrm{e}}\end{array}$ & 0.00 \\
\hline$T_{3}: 10$ & $\begin{array}{c}45.4 \\
(6.772)^{\mathrm{d}}\end{array}$ & $\begin{array}{c}32 \\
(5.700)^{d}\end{array}$ & $\begin{array}{c}353 \\
(18.801)^{\mathrm{d}}\end{array}$ & 35.30 \\
\hline$T_{4}: 100$ & $\begin{array}{c}54.4 \\
(7.484)^{c}\end{array}$ & $\begin{array}{c}44.8 \\
(6.727)^{c}\end{array}$ & $\begin{array}{c}1195 \\
(34.576)^{c}\end{array}$ & 11.95 \\
\hline$T_{5}: 1000$ & $\begin{array}{c}196 \\
(14.018)^{\mathrm{a}}\end{array}$ & $\begin{array}{l}84 \\
(9.191)^{\mathrm{a}}\end{array}$ & $\begin{array}{c}2732 \\
(52.253)^{b}\end{array}$ & 2.73 \\
\hline$T_{6}: 10,000$ & $\begin{array}{c}131.6 \\
(11.493)^{b}\end{array}$ & $\begin{array}{c}63.4 \\
(7.992)^{b}\end{array}$ & $\begin{array}{c}3116 \\
(55.826)^{\mathrm{a}}\end{array}$ & 0.31 \\
\hline $\operatorname{S.Ed}( \pm)$ & 0.11 & 0.08 & 0.43 & \\
\hline $\mathrm{CD}_{0.05}$ & 0.23 & 0.19 & 0.87 & \\
\hline
\end{tabular}

Values of numbers of galls, egg masses and final nematode population within parentheses are square root $(\sqrt{\mathrm{x}+0.5})$ transformed data

Mean followed by the same letter in the superscript(s) are statistically at par 
Fig.1 Effect of different inoculum levels on plant height $(\mathrm{cm})$ of Pumpkin cv Karbi-I

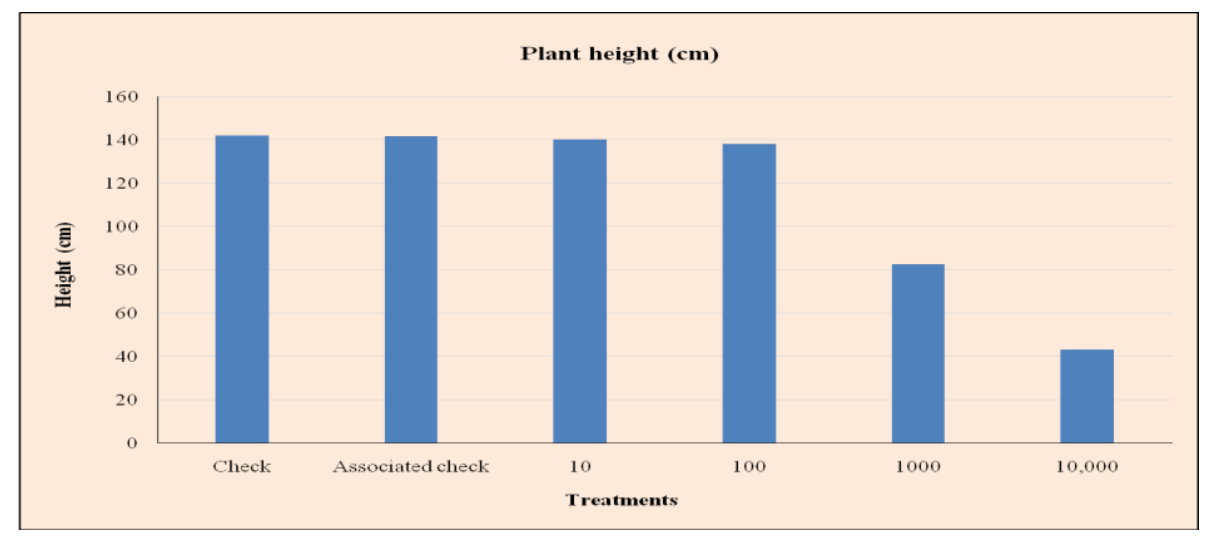

Fig.2 Effect of different inoculum levels on shoot and root weight (fresh and dry) of Pumpkin cv Karbi-I

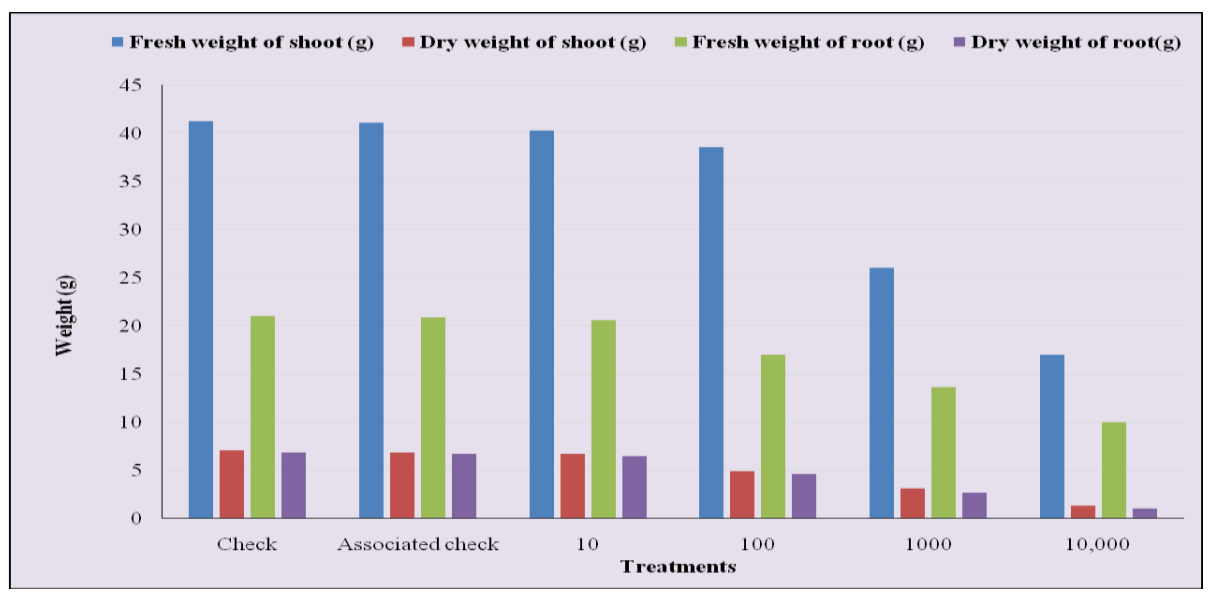

Fig.3 General view of the experiment - pathogenicity of Melodogyne incognita on pumpkin

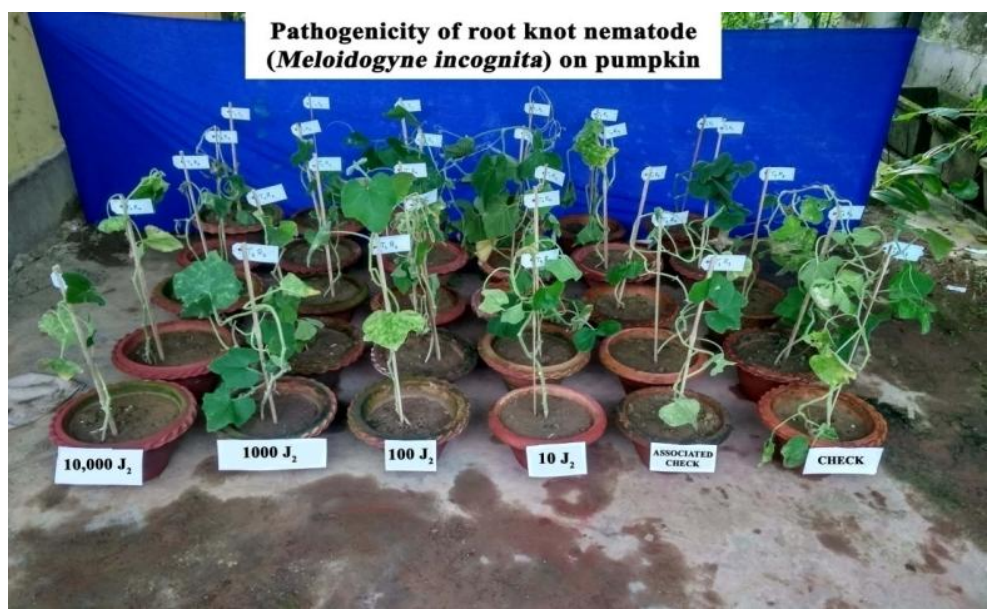


Fig.4 Growth of pumpkin under different inoculum levels of Meloidogyne incognita

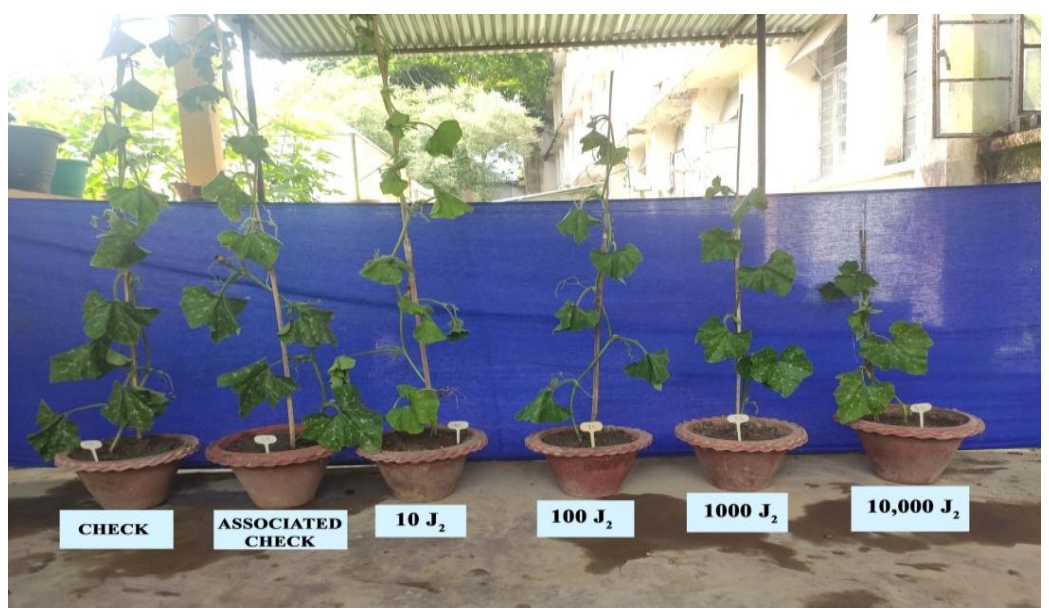

Fig.5 Effect of different inoculum levels of Meloidogyne incognita on number of galls and eggmasses on Pumpkin cv Karbi -I

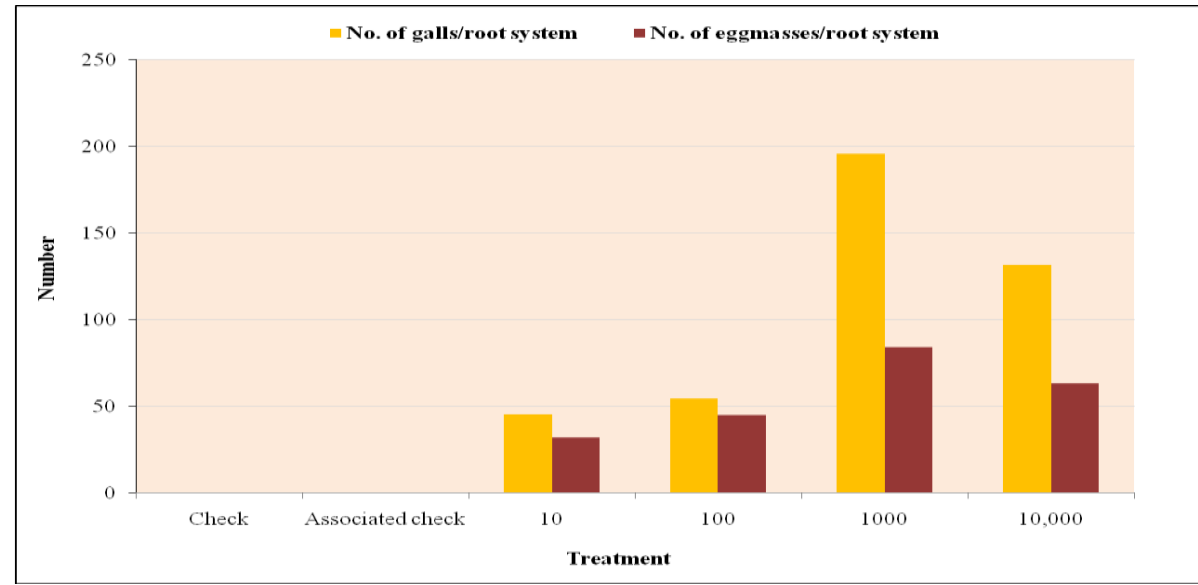

Fig.6 Effect of different inoculum levels on final nematode population of Meloidogyne incognita

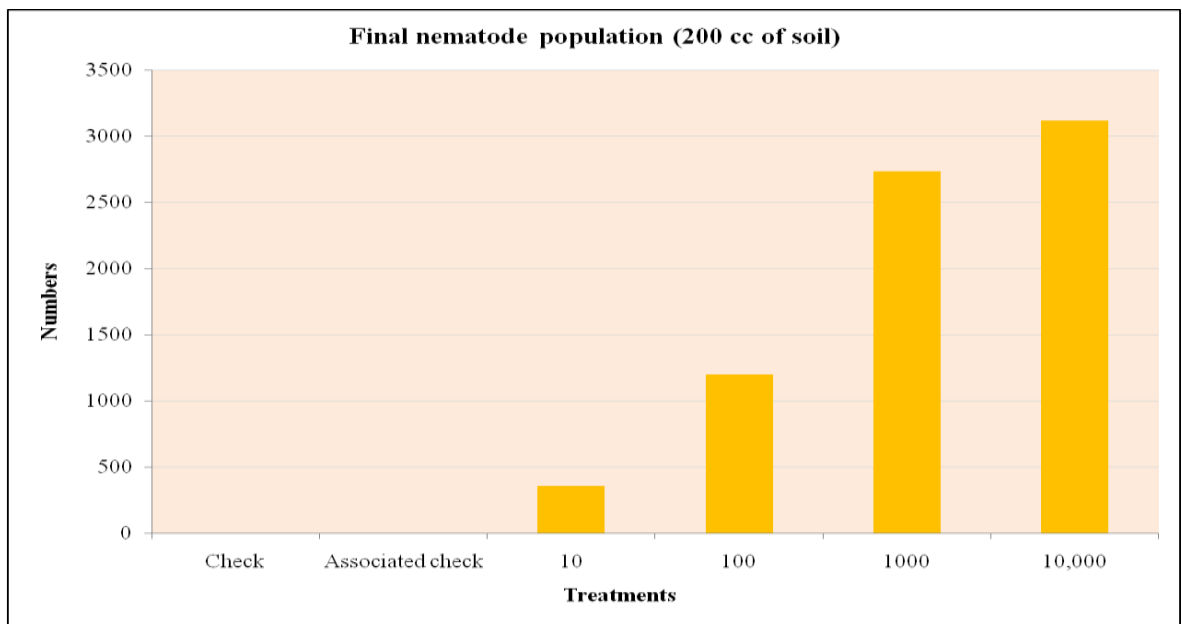


Fig.7 Effect of different inoculums level of Meloidogyne incognita on root growth of pumpkin

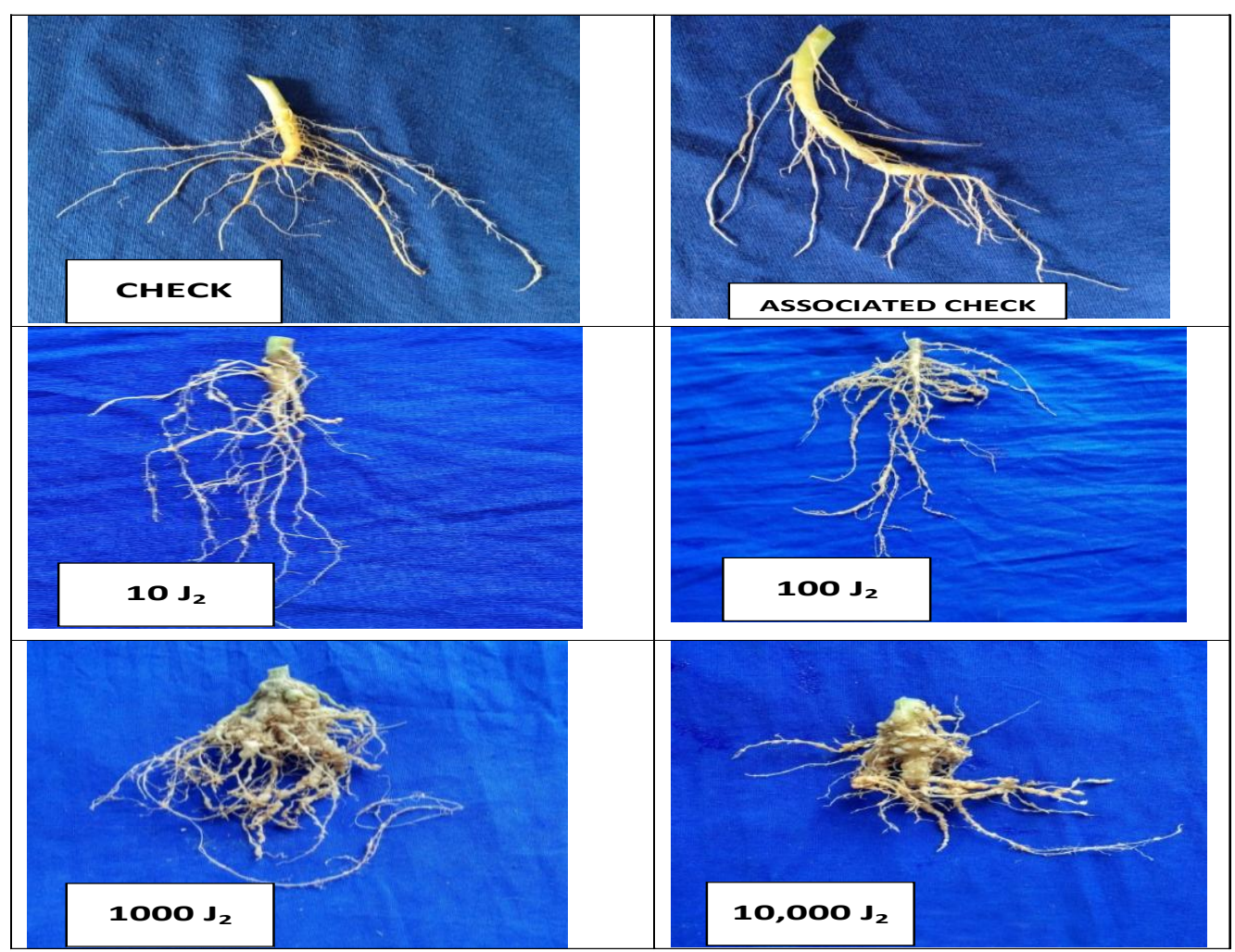

This finding is in agreement with the findings obtained by Sable and Darekar (1985) on bitter gourd, Dhankar et al., (1986) on watermelon. Similar findings had also been recorded by Savitri (2006) on Gherkin (small variety of cucumber) and Ash gourd, Singh (2011) on bottle gourd. Further, it is observed that there was a significant reduction in plant height of pumpkin at and above $100 \mathrm{~J}_{2}$ per pot. Similar results were also obtained by Bharali (1996) on cucumber, Savitri (2006) on Ash gourd.

The growth parameters of the crop were severely affected with increasing inoculum levels of the nematode which might be due to the destruction of the root system which ultimately affected the nutrient and water uptake. There was a corresponding reduction in fresh and dry weight of shoot of the plants with increase in level of inoculums from 10 to $10,000 \mathrm{~J}_{2}$ per pots. Similar, results were reported by Gupta et al., (1999) on bitter gourd in case of $M$. javanica. Mahapatra et al., (1999) on pointed gourd and Singh (2011) on bottle gourd. The results further revealed that there was a progressive decrease in root weight (fresh and dry) when the inoculum level of $M$. incognita increased. This finding is in conformity with that of Bharali (I996) who reported significant reduction in fresh and dry root weight on cucumber, Mahapatra et al., (1999) on pointed gourd, Savitri (2006) on Ash gourd. Further, it was observed that the plants at highest inoculum level $(100,000$ $\mathrm{J}_{2}$ per pot) had a poor stand, root system was very much reduced and feeder roots were completely absent. Similar, results were 
reported by Dhankar et al., (1986) on watermelon and also by Bharali (1996) on cucumber. There were a progressive increase in number of galls and egg masses with increase in inoculum level from 10 to 1000 and declined at 10,000 inoculum level per pot. However, it may be due to lack of sufficient feeding site for the nematode at highest inoculum level of $10,000 \mathrm{~J}_{2}$ per $\mathrm{kg}$ of soil. Similar, findings were obtained by Paruthi and Gupta (1985) on bottle gourd, Dhankar et al., (1986) on watermelon and Bharali (1996) on cucumber.There was a progressive increase in nematode population in pot soil with the increase in inoculum level from 10 to $10,000 \mathrm{~J}_{2}$ per pot. A gradual increase in nematode population with increase in the inoculum level was reported by Venkatesan (2009) on bitter gourd, Singh (2011) on bottle gourd. A gradual decrease in reproductive rate was observed with the increase of inoculum level of Meloidogyne incognita from $10 / \mathrm{kg}$ to $10,000 / \mathrm{kg}$ soil. Maximum reproductive rate (35.30) was recorded in the inoculum level of $10 \mathrm{~kg}$ of soil while minimum reproductive rate of (0.31) was recorded in the highest inoculum level of 10,000 per $\mathrm{kg}$ soil. This variation in growth rate of $M$. incognita may be attributed to competition for food and overcrowding condition at higher inoculum level. Similar, findings were reported by Verma and Anwar (1995) on pointed gourd and Singh (2011) on bottle gourd.

\section{References}

Anonymous (2011). Biennial Report, AICRP on Nematodes in cropping systems, Jorhat, Assam. p. 18.

Anonymous (2018). Annual Report. National
Horticulture Board of India. pp. 34-50.

Dhankar, R.K.S.; Sharma, C.; Sarna, N.T. and Trivedi, P.C. (1986). Pathogenicity of Meloidogyne incognita on watermelon (Citrullus vulgaris Scharad). Indian J. Nematol. 16(2): 274.

Gupta, D.C.; Paruthi, I.J. and Jain, R.K. (1999). Effect of initial inoculum levels of Meloidogyne spp. on some cucurbitaceous crops. Indian J. Nematol. 25(2): 194-199.

Mahapatra, S.N.; Swain, P.K. and Behera, B. (1999). Pathogenicity and management of root-knot nematode (Meloidogyne incognita) in pointed gourd (Trichosanthes dioica). Indian J. Agric. Sci. 69: 275-277.

Paruthi, I.J. and Gupta, D.C. (1985). Pathogenicity of root knot nematode, Meloidogyne javanica on bottle gourd (Lagenaria siceraria) using two methods of inoculation. Indian J. Nematol. 15(1): $52-54$.

Sable, A.N. and Darekar, K.S. (1985). Pathogenicity of Meloidogyne incognita to bitter-gourd, Momordica charantia L. Intern. Nematol. Net. Newsl. 2(4): 13-14

Singh, T. (2011). Investigations on root-knot nematodes (Meloidogyne spp.) on bottle gourd. M.Sc. (Agri.) Thesis on Nematology, submitted to Anand Agricultural University, Anand.

Venkatesan, M. (2009). Investigations on rootknot nematodes (Meloidogyne spp.) in bitter gourd. M.Sc. (Agri.) Thesis on Nematology, submitted to Anand Agricultural University, Anand.

Verma, A.C. and Anwar, A. (1995). Pathogenicity of Meloidogyne incognita in pointed gourd (Trichosanthes dioica). Indian J. Mycol. Pl. Pathol. 25: 70.

\section{How to cite this article:}

Lalhruaitluanga, Pc. and Koilash Hazarika. 2020. Pathogenicity of Meloidogyne incognita on Cucurbita Pepo. Int.J.Curr.Microbiol.App.Sci. 9(11): 771-777.

doi: https://doi.org/10.20546/ijcmas.2020.911.093 